\title{
Comparison Of Serum Testosterone, Luteinizing Hormone And Follicle Stimulating Hormone Levels In Diabetics And Non- Diabetics Men -A Case -Control Study
}

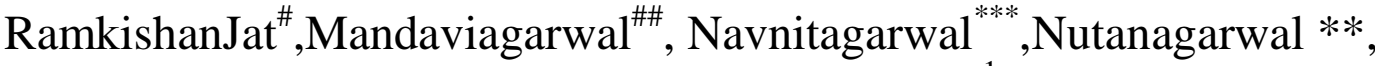 \\ Kuldeepchandel ${ }^{*}$, Zaki siddiqui ${ }^{1}$. \\ ***Professor and HOD, department of medicine, m.l.b .medical college jhansi \\ ** professor, department of medicine, M.L.B medical college Jhansi \\ *assistant professor , department of medicine ,M.L.B. medical college Jhansi \\ ${ }^{l}$ assistant professor, department of medicine M.L.B. medical college Jhansi \\ ${ }^{\#}$ lecturer, department of medicine, M.L.B. medical college Jhansi \\ ${ }^{\#}$ junior resident, department of medicine, M.L.B. medical college Jhansi
}

\begin{abstract}
:
Background: men with diabetes mellitus 2 have been claimed to have low level of serum testosterone than Non-Diabetic men.the aim of this study was to investigate if there is any relation of serum level of total and free testosterone,LH and FSH with diabetes mellitus 2,risk factor for CAD in diabetic men,HbAlc,and duration of diabetes mellitus.

Methods: In this case control study, 80 male subjects with diabetes mellitus type 2 ,between 30-70 years age ,attending Diabetic OPD and admitted in medicine ward of M.L.B Medical college was taken as cases.40 Age $\&$ sex matched healthy controls were taken from the medicine OPD. Study was done between march 2012 and february 2013.relationship with serum level of free and total testosterone, LH and FSH as well as other factors including age,risk factors for CAD,HbAlc, and duration of diabetes mellitus were investigated.

Results: Serum FT concentration is lower in type 2 diabetic patients compared with non-Diabetic men and low serum free testosterone in diabetes correlates positively with reduced sexual desire, low HDL, increased BMI, high serum triglyceride, increase total cholesterol and LDL level. Low serum free testosterone is also significantly associated with increased risk for coronary artery disease in diabetic patients. suggesting further research to better understand the underlying biologic mechanisms. free and total testosterone than non-diabetic
\end{abstract}

\section{Introduction}

Diabetic men have significantly lower concentration of free and total testosterone than non-diabetic men $^{1,2}$. Testosterone levels are not only lower in menwith type $2 \mathrm{DM}$, but also that the risk of developing type 2 DM is increased in men with low testosterone levels ${ }^{3,4}$.Hypogonadism has also been reported in diabetic men.Massachusetts Male Aging study and others prospectively suggest that low concentration of serum testosterone had been related to the development of insulin resistance, which is an important cause for inducing type 2 diabetes mellitus, hyperglycemia, dyslipidemia, and coronary artery diseases ${ }^{5}$. Some authors suggest that, at physiological levels, testosterone has a role in maintaining normal insulin sensitivity in men, an effect that is lost at low or high concentrations ${ }^{6}$. Other studies have shown that administration of testosterone to hypogonadal middle-aged men improves insulin sensitivity and glucose homeostasis ${ }^{7,8}$. The prevalence rate ofsymptomatic hypogonadism in men with type 2 DM is high and documented rates range from $20-64 \%$ with higher prevalence rates reported in the elderly'.

Thus the purpose of the present study was to evaluate the relationship between type $2 \mathrm{DM}$ and serum testosterone, $\mathrm{LH}$ and FSH level and to evaluate its association with other conventional risk factors for diabetes mellitus.

\section{Aims And Objectives}

1. To evaluate the relationship between diabetes mellitus type 2 and serum testosterone levels.

2. To study the relationship of serum testosterone level with other conventional risk factors for diabetes mellitus.

3. To study the serum testosterone level with duration of diabetes.

4. TO study the relationship between diabetes mellitus type 2 and LH and FSH. 
Methods

This case control study was conducted at the diabetic clinic of Maharani Laxmi Bai medical college ,Jhansi(India) during March 2012 to February 2013.eighty male type 2 diabetes mellitus patients from 30 to 70 years were selected from patients who attended to the diabetic clinic.

. Age \& sex matched healthy controls were taken from the medicine OPD. Inclusion criteria for diabetic patients were following;-

(based on National Diabetes Data Group, WHO, American Diabetes Association, 2011) (10,11 $^{1}$

1. Symptoms of diabetes plus random blood concentration $\geq 11.1 \mathrm{mmol} / \mathrm{L}$. (200mg/dl). Random is defined as without regard to time since the last meal.

OR

2. Fasting plasma glucose $\geq 7 \mathrm{mmol} / \mathrm{L}$ ( $\geq 126 \mathrm{mg} / \mathrm{dl}$ ). Fasting is defined as no calories intake for at least 8 hrs.

OR

3. $\mathrm{HbA} 1 \mathrm{C}>6.5 \%$

OR

4. Two hours plasma glucose $\geq 11.1 \mathrm{mmol} / \mathrm{L}(\geq 200 \mathrm{mg} / \mathrm{dl})$ during an oral glucose tolerance test with $75 \mathrm{mg}$ anhydrous glucose dissolved in water.

\section{Exclusion criteria}

Patients taking drugs which are known to interfere with serum testosterone levels for example, glucocorticoids, hormone replacement therapy, ketoconazole, opiods, methadone, heroin and marijuana.,Patients with features associated with congenital GnRH deficiency (midline facial defects, synkinesis or a family history of GnRH deficiency or anosmia).History oftumor, exposure to radiation, history of head trauma, spinal cord injuries, history of pelvic trauma and surgery.Any disease other than diabetes known to cause autonomic dysfunction. Any other chronic disease such as human immunodeficiency virus (HIV), end-stage renal disease, cirrhosis of liver and psychiatric disease.etc were excluded from the study

All 80 male patients with type 2 diabetes mellitus and 40 controls after informed consent, were studied based on the detailed history, anthropometric measurements, relevant blood investigations, HbA1C, ECG changes and estimation of serum total testosterone and LH and FSH. Estimation of cardiac markers was done wherever required.

TT was measured by fully automated bi directionally interfaced chemiluminescentimmunoassay(CLIA) And FT was measured by radio immune assay(RIA),

Normal levels of TT were taken as 300-1000ng/dl and normal levels of FT as 9-40pg/ml.

In all men LH/FSH were measured by chemiluminescentimmunoassay(CLIA).

Normal level of LH were taken as $2.0-12.0 \mathrm{miu} / \mathrm{ml}$

Normal level of FSH were taken as 1.0-12.0 miu/ml.

Stastistical analysis

the data are presented as means \pm standard deviation(SD).

For different qualitative parameters mean and standard deviation calculated. To compare the means between two groups, student unpaired ' $t$ ' test is used. Level of significance is taken as $p<0.05$.

Chi square test is used to find the association between two qualitative variables.

\section{Results}

Mean of age in diabetic patient was $48.32 \pm 8.20$ years and in non-diabetic $47.02 \pm 9.42$ years $(\mathrm{p}$ value $=0.042) .($ table 1$)$

Fasting blood sugar in diabetic patients $(134.53 \pm 15.5)$ was significantly higher in comparison to nondiabetic controls $(110 \pm 6.81)$ ( $\mathrm{p}$ value $<0.001$ ) (table 1).

Mean free testosterone concentrations in diabetic men(7.65 \pm 2.14$)$ were significantly lower in comparison tonon-diabetic men $(11.17 \pm 2.30)(\mathrm{p}<0.001)$. (table 1).

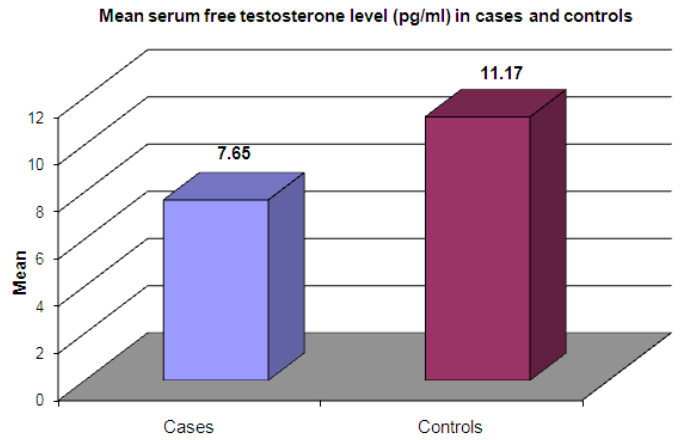

www.iosrjournals.org 
Mean Total testosterone concentrations in diabetic men(300.72 \pm 33.14$)$ were significantly lower in comparison to non-diabetic men $(383.81 \pm 57.63)(\mathrm{p}<0.001)$.(table 1$)$.

But there was no significant difference between two groups in the means of LH and FSH.(Table 1)

Table 1 General characteristics of study population (Mean \pm SD)

\begin{tabular}{|l|c|c|l|}
\hline \multicolumn{1}{|c|}{ Parameters } & Diabetic group & Control group & p value \\
\hline Age (in yrs) & $48.32 \pm 8.20$ & $47.02 \pm 9.42$ & 0.442 \\
\hline WHR & $1.04 \pm 0.09$ & $1.02 \pm 0.08$ & 0.324 \\
\hline BMI $\left(\mathrm{kg} / \mathrm{m}^{2}\right.$ ) & $27.11 \pm 4.57$ & $27.07 \pm 3.70$ & 0.964 \\
\hline Total testosterone (ng/dl) & $300.72 \pm 33.14$ & $383.81 \pm 57.63$ & $<0.001$ \\
\hline Free testosterone (pg/ml) & $7.65 \pm 2.14$ & $11.17 \pm 2.30$ & $<0.001$ \\
\hline LH(miu/ml) & 5.53 & 6.22 & 0.150 \\
\hline FSH(miu/ml) & 5.82 & 6.49 & 0.144 \\
\hline Hemoglobin $(\mathrm{g} / \mathrm{dl})$ & $11.04 \pm 1.78$ & $13.43 \pm 1.23$ & $<0.001$ \\
\hline TLC & $6905.37 \pm 1522.83$ & $6605 \pm 1259.48$ & 0.255 \\
\hline HbA1c $(\%)$ & $8.05 \pm 1.44$ & $5.07 \pm 0.44$ & $<0.001$ \\
\hline T. cholesterol (mg\%) & $201.95 \pm 26.96$ & $188.12 \pm 17.39$ & 0.004 \\
\hline Triglycerides (mg\%) & $153.57 \pm 12.41$ & $124.45 \pm 31.15$ & $<0.001$ \\
\hline LDL (mg\%) & $114.63 \pm 26.71$ & $102.97 \pm 20.03$ & $<0.001$ \\
\hline HDL (mg\%) & $36.16 \pm 5.62$ & $45.8 \pm 7.20$ & $<0.001$ \\
\hline FBS (mg\%) & $134.53 \pm 15.5$ & $110 \pm 6.81$ & $<0.001$ \\
\hline RBS (mg\%) & $195.2 \pm 35.84$ & $145.07 \pm 6.76$ & $<0.001$ \\
\hline
\end{tabular}

Table 2Distribution of low serum Total and Free testosterone,LH and FSH level in cases (DM2) and controls (Non-diabetic)

\begin{tabular}{|c|c|c|c|c|c|}
\hline \multirow{2}{*}{ Low serum level } & \multicolumn{2}{|c|}{ Case } & \multicolumn{2}{|c|}{ Control } & \multirow{2}{*}{ P value } \\
\cline { 2 - 7 } & No. & No. & 08 & 25 & 0.020 \\
\hline Total testosterone & 23 & 28.75 & 08 & 25 & 0.029 \\
\hline Free testosterone & 46 & 57.5 & 04 & 10 & 0.688 \\
\hline LH & 10 & 12.5 & 03 & 7.5 & 0.519 \\
\hline FSH & 09 & 11.25 & & & \multirow{2}{*}{0} \\
\hline
\end{tabular}

The serum total testosterone was decreased in 23 cases $(28.75 \%)$ and 8 controls $(25 \%)$, and the difference was statistically significant.

The serum free testosterone was decreased in 46 cases $(57.5 \%)$ and 8 controls $(25 \%)$, and the difference was statistically significant.

The serum LH level was decreased in 10 cases(12.5\%) and 04 controls(10\%), and the difference was statistically not significant.

The serum FSH level was decreased in 09 cases(11.25\%) and 03 controls(7.5\%), and the difference was statistically not significant.

Table 3Serum total testosterone level and DM2 and CAD cross tabulation

\begin{tabular}{|l|c|c|c|}
\hline S. total testosterone & DM2 with CAD $(\mathbf{n = 2 0})$ & $\begin{array}{c}\text { DM2 } \\
(\mathbf{n = 6 0})\end{array}$ & P value \\
\hline$<300 \mathrm{ng} / \mathrm{dl}$ & 7 & 16 & 0.39 \\
\hline$\geq 300 \mathrm{ng} / \mathrm{dl}$ & 13 & 44 & 0.411 \\
\hline
\end{tabular}

7 patients of DM2 with CAD (23.7\%) and 16 patients of DM2 (26.67\%) had subnormal level of serum total testosterone and the difference was statistically not significant.

Table 4 Serum free testosterone level and DM2 and CAD cross tabulation

\begin{tabular}{|c|c|c|c|}
\hline S. free testosterone & $\begin{array}{c}\text { DM2 with CAD } \\
(\mathbf{n = 2 0})\end{array}$ & $\begin{array}{c}\text { DM2 } \\
(\mathbf{n = 6 0})\end{array}$ & P value \\
\hline$<9 \mathrm{pg} / \mathrm{ml}$ & 13 & 33 & 0.037 \\
\hline$\geq 9 \mathrm{pg} / \mathrm{ml}$ & 07 & 27 & 0.192 \\
\hline
\end{tabular}

13 patients of DM2 with CAD (65\%) and 33 patients of DM2 $(55.6 \%)$ had subnormal level of serum free testosterone, and difference was statistically significant. 
Comparison Of Serum Testosterone, Luteinizing Hormone And Follicle Stimulating Hormone ...

Table 05 Distribution of HDL-C level with low level of free testosterone

\begin{tabular}{|l|c|c|c|c|}
\hline \multirow{2}{*}{$\begin{array}{c}\text { HDL-C } \\
(\mathbf{m g} / \mathbf{d l})\end{array}$} & $\begin{array}{c}\text { Cases with low } \\
\text { FT }\end{array}$ & Total Cases & $\begin{array}{c}\text { Controls with } \\
\text { low FT }\end{array}$ & Total Controls \\
\cline { 2 - 5 } & No & No & No & No \\
\hline$<40$ & $32(58.2 \%)$ & 55 & $04(30.7 \%)$ & 13 \\
\hline$\geq 40$ & $14(56 \%)$ & 25 & $04(14.8 \%)$ & 27 \\
\hline
\end{tabular}

$\mathrm{P}$ value 0.00011

Above table shows that amongst cases and controls 32 patients $(58.18 \%)$ in case group and 4 subjects $(30.76 \%)$ in control group had HDL-C $<40$, and the difference was statistically significant.

Table 06 Distribution of LDL-cholesterol level with low level of free testosterone

\begin{tabular}{|l|c|c|c|c|}
\hline \multirow{2}{*}{ LDL-C(mg/dl) } & $\begin{array}{c}\text { Cases with low } \\
\text { FT }\end{array}$ & Total Cases & $\begin{array}{c}\text { Controls with low } \\
\text { FT }\end{array}$ & Total Controls \\
\cline { 2 - 5 } & No. & No. & No. & No. \\
\hline$<100$ & $23(40.9 \%)$ & 49 & $04(18.18 \%)$ & 22 \\
\hline $100-129$ & $01(100 \%)$ & 01 & $01(7.6 \%)$ & 13 \\
\hline $130-159$ & $21(75 \%)$ & 28 & $03(75 \%)$ & 04 \\
\hline$\geq 160$ & $01(50 \%)$ & 02 & $0(0 \%)$ & 01 \\
\hline
\end{tabular}

$\mathrm{P}$ value $=0.0012$

In the case group, 23 out of 31 patients $(77.4 \%)$ had high LDL-C levels while in control group 4 out of $18(22.22 \%)$ had higher than normal LDL-C level, and the difference was statistically significant.

Table 07 Relation of serum testosterone, LH and FSH level with duration of diabetes

\begin{tabular}{|c|c|c|c|c|}
\hline \multirow[b]{2}{*}{ Serum testosterone levels } & \multicolumn{3}{|c|}{ Duration of diabetes } & \multirow[t]{2}{*}{ P value } \\
\hline & $\begin{array}{c}<1 \text { year } \\
(\mathrm{n}=30)\end{array}$ & $\begin{array}{c}1-5 \text { years } \\
(n=22)\end{array}$ & $\begin{array}{c}>5 \text { years } \\
(n=28)\end{array}$ & \\
\hline Total testosterone $(<300 \mathrm{ng} / \mathrm{dl})$ & 03 & 08 & 12 & 0.014 \\
\hline Free testosterone $(<9 \mathrm{ng} / \mathrm{dl})$ & 14 & 14 & 18 & 0.315 \\
\hline LH & 03 & 04 & 03 & 0.637 \\
\hline FSH & 03 & 03 & 03 & 0.914 \\
\hline
\end{tabular}

In case group 28 patients (35\%) had DM2 for $>5 \mathrm{yrs}$, And 22 patients (27.5\%) with duration between 1-5 yrs. 30 patients $(37.5 \%)$ had DM2 <1yr. (newly diagnosed cases of DM2)

Among the patient with DM 2 for $>5 y r s, 12(42.85 \%)$ and 18(64.28\%) had low levels of serum total and free testosterone respectively.

And 03(10.71\%) had low levels of both LH and FSH hormones. these difference were statistically significant only for total testosterone.

Table 08 Distribution of low serum total/free testosterone, with HbA1c level

\begin{tabular}{|c|c|c|c|c|c|c|c|c|c|}
\hline \multirow{3}{*}{ Low serum level } & \multicolumn{8}{|c|}{ HbA1c } & \multirow[t]{3}{*}{ P value } \\
\hline & \multicolumn{2}{|c|}{$\begin{array}{c}<6.5 \\
(\mathrm{n}=8)\end{array}$} & \multicolumn{2}{|c|}{$\begin{array}{l}6.5-8.4 \\
(n=47)\end{array}$} & \multicolumn{2}{|c|}{$\begin{array}{c}8.5-10.4 \\
(n=17)\end{array}$} & \multicolumn{2}{|c|}{$\begin{array}{l}\geq 10.5 \\
(n=8)\end{array}$} & \\
\hline & No. & $\%$ & No. & $\%$ & No. & $\%$ & No. & $\%$ & \\
\hline Free testosterone & 02 & 25 & 30 & 63.82 & 08 & 47.06 & 06 & 75 & 0.112 \\
\hline
\end{tabular}

In case group serum total testosterone was decreased most in $3(37.5 \%)$ and $4(50 \%)$ patients with HbA1c $<6.5$ and $>10.5$ respectively.

Serum free testosterone was decreased most in $30(63.82 \%)$ and $06(75 \%)$ patients with HbA1c between 6.5-8.4 and >10.5 respectively. but these differences were statistically not significant.

\section{Discussion}

Diabetes mellitus is most common endocrine disorder which involves multiple organs and leads to significant morbidity and mortality due to accompanying complications. Erectile dysfunction, reduced libido, orgasmic dysfunction, and retrograde ejaculation are established complications found with variable prevalence in men with diabetes. Various studies have shown that patients with type 2 diabetes have frequent occurrence of hypogonadism as reflected by their low plasma concentration of free testosterone. (Tomar et al, 2006) ${ }^{12}$.

Coronary artery disease (CAD) is a major cause of mortality and morbidity in developed world, and in developing countries, the incidence is rising. Atherosclerosis is the major cause of CAD. CAD manifests as acute coronary syndrome (ACS) and stable angina.

Men are more than twice as likely as women to die from coronary heart disease, and this ratio is consistent in all population and is not related to differences in risk factors (British Heart Foundation Statistics Database, 1998). Low testosterone level are associated with CAD (English et al, 2000) ${ }^{15}$ and low serum 
testosterone is associated with increased aortic atheroma (Hak et al, 2002) ${ }^{14}$. Furthermore, low testosterone levels are associated with several risk factors for the development ofCAD including systolic and diastolic hypertension, adverse lipid profile, and high levels of fibrinogen and procoagulable factors (English et al, $2000)^{15}$.

In present study out of $26(32.5 \%)$ of obese patients with DM2, 16(61.51\%) had low levels of total testosterone and $20(76.9 \%)$ had low serum free testosterone. Whereas Dhindsaet al ${ }^{16}$ (2010) reported prevalence of low testosterone in obese diabetics to be $50 \%$. The phenomenon of testosterone deficiency in diabetic patients with higher BMI could be due to increase in adipose tissues mass which results in increased aromatase activity, leading to enhanced conversion of testosterone in to estradiol which further suppresses hypothalamic-pituitarytesticular axis and decreases testosterone secretion (Giagulli et al $\left.{ }^{17}, 1994\right)$. Adipose tissue, which is considered as an endocrine organ and produces a host of hormones and cytokines, may modulate insulin action and regulate leydig cell function. Leptin production is tightly coupled to insulin resistance and may play a key role in steroid biogenesis and reduced testosterone levels. Leptin levels have been shown to be inversely correlated with serum testosterone levels (Haffner et al, 1997; Luukkaa et al, 1998) ${ }^{18,19}$, and increased circulating leptin may be involved in the pathogenesis of leydig cell dysfunction (Isidori et $\mathrm{al}^{20}, 1999$ ). Other possible mechanism involved in pathogenesis of obesity related low testosterone is insulin resistance (Dhindsaet $\mathrm{al}^{16} 2010$ ).

In present study, 23 out of 80 type 2 diabetes mellitus patients $(28.75 \%)$ and 8 out of 40 controls $(25 \%)$ had low level of total testosterone in serum, whereas 46 out of 80 diabetes mellitus patients $(57.5 \%)$ and 8 out of 40 controls $(25 \%)$ had low levels of free testosterone. And 10 out of 80 type 2 diabetes mellitus patients $(12.5 \%)$ and 04 out of 40 controls $(10 \%)$ had low level of Serum LH in serum, whereas 09 out of 80 diabetes mellitus patients $(11.25 \%)$ and 03 out of 40 controls $(7.5 \%)$ had low levels of Serum FSH.

Mean serum total testosterone in cases was $300.72 \pm 33.14$ and in control group was $383.81 \pm 57.63$. The difference was statistically significant.

Mean serum free testosterone in cases was $7.65 \pm 2.04$ and in control group was $11.17 \pm 2.30$. The difference was statistically significant.

Mean serum LH level in cases was 5.53 and in control group was 6.22. The difference was statistically not significant.

Mean serum FSH level in cases was 5.82 and in control group was 6.49. The difference was statistically not significant.

In the study by Ernani et $\mathrm{al}^{21} 2005$, low levels of serum total testosterone was found in patients with diabetes mellitus (34\%) when compared to healthy control subjects $(23 \%)$.

In the study by Kapoor et $\mathrm{al}^{22} 2007$, low levels of total testosterone was found in $(25 \%)$ of patients with diabetes mellitus.

In the study by Ernaniet $\mathrm{al}^{21} 2005$ level of free testosterone was decreased in $46 \%$ of diabetics as compared to $24 \%$ in non-diabetics

In present study, prevalence of high cholesterol $(>200 \mathrm{mg} / \mathrm{dl})$ in diabetic patients was 18 out of $80(22.5 \%)$, of which all 18 patients $(100 \%)$ had low serum free testosterone level. Prevalence of low serum free testosterone among patients with high serum cholesterol in type 2 diabetes was $100 \%$ while $66.6 \%$ of controls had high serum cholesterol with low free testosterone.

In the present study, the mean total cholesterol in cases was $201.95 \pm 26.96 \mathrm{mg} / \mathrm{dl}$ and in controls $188.12 \pm 17.34 \mathrm{mg} / \mathrm{dl}$. The total cholesterol was higher in cases than controls and the difference was statistically significant.

In GMC Rosanoet $\mathrm{al}^{23} 2007$ study, total cholesterol was $247 \pm 25 \mathrm{mg} / \mathrm{dl}$. In Majon Muller et al ${ }^{24} 2003$

study, total cholesterol was $226.6 \pm 1.11 \mathrm{mg} / \mathrm{dl}$ and is comparable to our study.

The result of the present study and previous studies is in accordance with cardiovascular risk attributed to total cholesterol.

In present study, occurrence of low HDL ( $<40 \mathrm{mg} / \mathrm{dl})$ in diabetic patients was 55 out of 80( $68.75 \%$ ), of which 32 ( $85.18 \%$ ) had low serum free testosterone level.

Prevalence of low HDL $(<40 \mathrm{mg} / \mathrm{dl})$ in diabetic patients with low testosterone was 7 out of 55 $(58.18 \%)$ in present study whereas Mathis et $\mathrm{al}^{25}$ (2008) reported low testosterone levels in $28 \%$ cases.

The mean HDL cholesterol level in cases was $36.16 \pm 5.62 \mathrm{mg} / \mathrm{dl}$ and controls was $45.80 \pm 7.20 \mathrm{mg} / \mathrm{dl}$. The mean HDL-C level in Majon Muller et $\mathrm{al}^{24} 2003$ study was $51.81 \pm 0.33 \mathrm{mg} / \mathrm{dl}$. Then HDL-C level in KT Khawet $\mathrm{al}^{26} 2007$ study was $47.95 \pm 0.32 \mathrm{mg} / \mathrm{dl}$.

The lower level of HDL-C in case and control in our study is in accordance to the prevalent lipid status of South Asian population.

In the present study prevalence of raised LDL-C (>100) levels in DM2 patients was 38.75\% (31 out of 80) while in controls was $45 \%$ ( 18 out of 40 ).

Out of 31 cases, $23(74.1 \%)$ had low level of free testosterone and out of 18 controls, $4(22.2 \%)$ had low level of free testosterone. 
The mean LDL-cholesterol level in the present study was $114.63 \pm 26.79 \mathrm{mg} / \mathrm{dl}$ in cases and $102.97 \pm 20.03 \mathrm{mg} / \mathrm{dl}$ in controls, and the difference was statistically significant.

In Majon Muller et $\mathrm{al}^{24} 2003$ study, the mean LDL-C level was $150.42 \pm 0.98 \mathrm{mg} / \mathrm{dl}$.

In present study prevalence of high triglyceride $(<150 \mathrm{mg} / \mathrm{dl})$ in diabetic patients was 53 out of 80 $(66.25 \%)$ of which $36(78.26 \%)$ had low serum free testosterone level.

Prevalence of high triglyceride $(>150 \mathrm{mg} / \mathrm{dl})$ in control group was 10 out of $40(25 \%)$ of which 3 $(37.5 \%)$ had low free testosterone level.

The mean triglyceride level in the cases was $153.57 \pm 12.41$ and in controls $124.45 \pm 31.15$, the difference was not statistically significant.

Prevalence of elevated triglycerides $(>150 \mathrm{mg} / \mathrm{dl})$ in diabetic patients with low free testosterone was 36 out of 53(67.9\%)in present study whereas Mathis et $\mathrm{al}^{25}$ (2008) reported that prevalence of elevated triglyceride in diabetic patients with low testosterone levels was $45 \%$ in their study of 649 patients.

These findings indicate higher incidence of dyslipidemia in patients with low serum free testosterone. Low free testosterone was more commonly found in patients with high serum cholesterol (100\% vs $16.6 \%$ ), low HDL-C level (74.17\% vs. $22.2 \%)$ and high serum triglyceride $(68.755 \%$ vs $58.18 \%$ ) as compared to control group. Difference was statistically significant.

\section{V. conclusions}

The present study showed that serum free and total testosterone is lower intype 2 diabetic patients in compared with non-diabetic men.

This study shows that low serum free testosterone in diabetes correlates positively with low HDL, , high serum triglyceride, increase total cholesterol and LDL levels.

Low serum free testosterone is also significantly associated with increased risk for coronary artery disease in diabetic patients.

The results also showed that there was a non-significant negative relationship between serum free/totaltestosterone ANDHbA1c and Duration of diabetes.it may be because of small sample size and shorter duration of study,for these larger studies are required. However there were no significant differences between LH and FSH level in diabetic men compared to healthy controls.

Thus it is important to evaluate cases of diabetes with respect to free testosterone level for early detection and management of hypogonadism for better sexual and mental function of such patients.

\section{References}

[1]. Andersson B, Marin P, Lissner L, Vermeulen A, Bjorntorp P. Testosterone concentrations in women and men with NIDDM. DiabetesCare. 1994; 17:405-411

[2]. Barrett-Connor E. Lower endogenous androgen levels and dyslipidaemia in men with NIDDM. Ann Intern Med. 1992;117:807-811

[3]. Svartberg J. Epidemiology: testosterone and the metabolic syndrome. Int J Impot Res 2007; 19:124-8. Epub 2006 Jul 20.

[4]. J ClinEndocrinolMetab 2006; 91:4335-43. Epub 2006 Aug 22 Zitzman M, Faber S, Nieschlag E. Association of specific symptoms and metabolic risks with serum testosterone in older men

[5]. 8 Stellato RK, Feldman HA, Hamdy O, Horton ES, McKinlay JB. Testosterone, sex hormone-binding globulin, and the development of type 2 diabetes in middleaged men: prospective results from the Massachusetts Male Aging Study. Diabetes Care $2000 ; 23: 490-4$

[6]. 9 Livingstone C, Collison M. Sex steroids and insulin resistance. ClinSci (Lond) 2002; 102 : 151-66

[7]. 10 Marin P, Holmang S, Jonsson L et al. The effects of testosterone treatment on body composition and metabolism in middleaged obese men. Int J ObesRelatMetabDisord 1992; 16 : 991-7

[8]. 11 Boyanov MA, Boneva Z, Christov VG. Testosterone supplementation in men with type 2 diabetes, visceral obesity and partial androgen deficiency. Aging Male 2003; 6: 1-7

[9]. 7. Kalyani RR, Dobs AS. Androgen deficiency, diabetes, and the metabolic syndrome in men. CurrOpinEndocrinol Diabetes Obes2007; 14:226-34.

[10]. Powers AC. Diabetes Mellitus Harrison's principles of internal medicine $18^{\text {th }}$ edition ,vol-2,2012;344:2968-3003

[11]. ADA (American Diabetes Association). Diagnosis and Classification of Diabetes Mellitus .Diabetes Care; 2010 33:S62-S69.

[12]. Tomar R, Sandeep dhindsa,Ajaychoudhary. Contrasting testosterone concentration in type 1 and type 2 diabetes.Diabetes Care; 2006: 29:1120-1122

[13]. English KM, Mandour O, Steeds RP, Diver MJ, Jones TH, Channer KS. Men with coronary artery disease have lower levels of androgens than men with normal coronary angiograms. Eur Heart J 2000; 21; 890-4.

[14]. Hak AE, Witteman JCM, De Jong FH, Geerlings MI, Hofman A, Pols HAP. Low levels of endogenous androgens increase the risk of atherosclerosis in elderly men: The Rotterdam study. J ClinEndocrinol Metab:2002: 87:3632-3639

[15]. English KM, Mandour O, Steeds RP, Diver MJ, Jones TH, Channer KS. Men with coronary artery disease have lower levels of androgens than men with normal coronary angiograms. Eur Heart J 2000; 21; 890-4.

[16]. Dhindsa S; Michael G Miller; Cecilia L McWhirter; Donald E Mager; Husam... Testosterone Concentrations in Diabetic and Nondiabetic Obese Men;Diabetes Care; 2010; 33: 1186

[17]. Giagulli VA, Kauf man JM, VermeulenA; pathogenesis of the decreased androgen levels in obese men. J Clin. Endocrinal. Metab; 1994; 79,929-931.

[18]. 192Haffner SM, Miettinen H, Karhapa“ P, Mykka nen L, LaaksoM.Leptin concentrations, sex hormones, and cortisol in nondiabeticmen. J ClinEndocrinol Metab.1997; 82:1807-1809.

[19]. Luukkaa V, Pesonen U, Huhtaniemi I, Lehtonen A, TilvisR, Tuomilehto J, Houlu M, Huupponen R. Inverse correlationbetween serum testosterone and leptin in men. J ClinEndocrinolMetab. 1998;83:3243-3246 
[20]. Isidori AM, Caprio M, Strollo F, Moretti C, Frajese G, IsidoriA,Fabbri A. Leptin and androgens in male obesity: evidence forleptin contribution to reduced androgen levels. J ClinEndocrinolMetab. 1999; 84:3673-3680.

[21]. ERNANI L. RHODEN, EDUARDO P. RIBEIRO, CLAUDIO TELOKEN and CARLOS A.V. SOUTO; Diabetes mellitus is associated with subnormal serum levels of free testosterone in men. 2005 BJU International 96,867-870.

[22]. Roberto Fogari, Paola Preti, Annalisa Zoppi, Elena Fogari, Andrea Rinaldi, Luca Corradi and Amedeo Mugellini ,Serum Testosterone Levels and Arterial Blood Pressure in the Elderly Hypertension Research (2005) 28, 625-630

[23]. English KM, Mandour O, Steeds RP, Diver MJ, Jones TH, Channer KS. Men with coronary artery disease have lower levels of androgens than men with normal coronary angiograms. Eur Heart J 2000; 21:890-4.

[24]. Boulton AJ, Vinik AI, Arezzo JC, Bril V, Feldman EL, Freeman R, Malik RA, Maser RE,Sosenko JM, Ziegler D: Diabetic neuropathies: a statement by the American Diabetes Association.Diabetes Care;2005: 28:956-962.

[25]. Mathis Grossmann; Low Testosterone Levels are Common and Associated with Insulin Resistance in Men with Diabetes. Journal of Clinical Endocrinology \& Metabolism, 2008; 93: 1834-1840.

[26]. Haffner SM, Mykkanen 1, Valdez RA, Katz MS. Relationship of sex hormones to lipids and lipoproteins in nondiabetic men. J ClinEndocrinolMetab 1993; 77:1610-15. 